\title{
PEMETAAN DISTRIBUSI OBJEK WISATA DAN POTENSI WISATA DI KECAMATAN SUKAWATI
}

\author{
Putu Eka Supriyatama1 ${ }^{1}$ I Gede Astra Wesnawa ${ }^{2 *}$
}

Prodi Pendidikan Geografi,Universitas Pendidikan Ganesha, Indonesia

\section{A R T I C L E I N F O}

\section{Article history:}

Received 11 Januari 2019

Received in revised form

16 Februari 2019

Accepted 22 Maret 2019

Available online 31 Maret 2019

\section{Kata Kunci: \\ pemetaan, objek wisata, dan tingkat kelayakan}

\section{Keywords:}

mapping, attractions, and level of feasibility

\begin{abstract}
A B S T R A K
Penelitian ini dilaksanakan di Kecamatan Sukawati dengan tujuan: (1) mengidentifikasi karakteristik objek wisata di Kecamatan Sukawati, (2) menganalisis tingkat kelayakan pengembangan objek wisata di Kecamatan Sukawati, dan (3) memetakan distribusi objek wisata di Kecamatan Sukawati. Rancangan penelitian yang digunakan adalah deskriptif kualitatif dengan sampling pelaku usaha wisata dan teknik purposive sampling. Metode yang digunakan dalam penelitian adalah metode observasi, wawancara, angket, dokumentasi, dan pencatatan dokumen. Hasil penelitian menunjukan, (1) Karakteristik objek wisata di Kecamatan Sukawati yang meliputi: (a) wisata alam seperti: Hidden Canyon Beji Guwang, dan Pantai Purnama, (b) wisata budaya seperti: Cagar Budaya Pura Puseh dan Putra Barong, (c) wisata buatan seperti: Bali Zoo Park dan Museum Seni Batuan, (d) wisata minat khusus seperti: Pasar Seni Sukawati. (2) Tingkat kelayakan pengembangan objek wisata Kecamatan Sukawati. (3) Pemetaan distribusi objek wisata
\end{abstract} di Kecamatan Sukawati: (a) Peta Karakteristik Objek Wisata, dan (b) Peta Tingkat Kelayakan Pengembangan Objek Wisata Di Kecamatan Sukawati.

\section{A B S T R A C T}

This research was conducted in Sukawati District with the aim: (1) identify the characteristics of attractions in Sukawati District, (2) analyze the level of feasibility of developing a tourist attraction in Sukawati District, and (3) map the distribution of attractions in Sukawati District. The research design used was qualitative descriptive by sampling tourism businesses and purposive sampling techniques. The method used in the study is the method of observation, interviews, questionnaires, documentation, and recording documents. The results of the study show, (1) Characteristics of attractions in Sukawati District which include: (a) natural tourism such as: Hidden Canyon Beji Guwang, and Purnama Beach, (b) cultural tourism such as: Pura Puseh Cultural Reserve, and Putra Barong, (c) artificial tours such as: Bali Zoo Park, and Batuan Art Museum, (d) special interest tours such as: Sukawati Art Market. (2) The level of feasibility of developing a tourist attraction in Sukawati District. (3) Mapping the distribution of attractions in Sukawati district: (a) Map of Characteristics of Tourism Objects, and (b) Feasibility Map for Development of Tourism Objects in Sukawati district.

\footnotetext{
* Corresponding author.

E-mail addresses:cahayapagi28@gmail.com ${ }^{1}$ igedeastra62@gmail.com²
} 


\section{Pendahuluan}

Pariwisata telah menjadi salah satu industri terbesar di dunia, dan merupakan andalan utama dalam menghasilkan devisa di berbagai negara. Di dunia, Bali terkenal sebagai tujuan pariwisata yang berlandaskan kepada Kebudayaan Bali yang dijiwai oleh ajaran Agama Hindu dan falsafah Tri Hita Karana. Sebagai magnet pariwisata di Indonesia, beberapa daerah di Bali dibangun menjadi daerah kawasan wisata. Hal tersebut ditujukan untuk meningkatkan peran dan kesejahteraan masyarakat seluas-luasnya serta penyiapan sumber daya manusia yang memiliki kompetensi tinggi di bidang pelayanan jasa kepariwisataan juga menjadi hal yang perlu dilakukan serta perlu pula dilengkapi dengan kemampuan teknis, operasional dan manajerial dalam penyediaan barang dasa kepariwisataan (Simamora dan Sinaga, 2016). Industri pariwisata di Bali sampai sekarang berpusat di kawasan Bali Selatan seperti Denpasar, Badung, dan Gianyar. Pembangunan suatu obyek wisata harus dirancang dengan bersumber pada potensi daya tarik yang dimiliki oleh objek tersebut, dan harus mengacu pada berbagai kriteria kelayakan (Subhani, 2010). Pariwisata di daerah tersebut berkembang dengan pesat, karena memiliki fasilitas yang lengkap.

Berbeda dengan kawasan Badung dan Denpasar, daerah Gianyar memiliki potensi wisata yang khas dan unik yaitu terletak pada wisata budaya. Hal ini menjadikan Kabupaten Gianyar sebagai pusat seni sekaligus icon seni di Pulau Dewata. Sukawati sebagai salah satu kawasan wisata yang terkenal di Kabupaten Gianyar setelah Ubud memperlihatkan corak yang sama dengan daerah lain yaitu budaya. Daerah tujuan wisata di Kecamatan Sukawati yang sudah terdata di Dinas Pariwisata Daerah Kabupaten Gianyar Tahun 2018 adalah sebesar 16\% dari total $100 \%$ daya tarik wisata yang tersebar di Kabupaten Gianyar. Persentase tersebut belum mewakili keseluruhan jumlah objek wisata yang ada di Kecamatan Sukawati, hal ini dikarenakan adanya beberapa objek yang masih belum terdata.

Mengacu pada survei yang ada pada website resmi Dinas Pariwisata Daerah Kabupaten Gianyar, sampai saat ini tidak tersedianya penunjuk jalan yang cukup menjadi masalah bagi wisatawan sehingga daya tarik yang ingin dikunjungi sulit ditemukan, padahal daya tarik tersebut telah mereka lalui sebelumnya("PERMASALAHAN YANG MEMPENGARUHI DAYA TARIK WISATA DI GIANYAR," n.d.). Hal ini berlaku bagi wisatawan yang tidak diantar oleh guide, artinya mereka melakukan perjalanan secara individual. Adanya fasilitas rute untukpengunjung dapat mengetahui rute perjalanan yang harus di lalui untuk sampai ke tempat tujuan. Pengunjung yang belum mengetahui jalan menuju titik lokasi obyek wisata, dapat dipermudah dengan fasilitas rute ini sebagai petunjuk arah (Richard, 2014).

Untuk daerah tujuan wisata di Kecamatan Sukawati ketersediaan media berupa brosur di objek wisata yang ada hanya menggambarkan kekhasan objek wisata bersangkutan, petunjuk jalan yang disediakan oleh pemerintah masih minim dan terkesan hanya untuk objek wisata yang sudah popular, sedangkan untuk peta wisata yang khusus memberikan informasi mengenai kondisi pariwisata di Kecamatan Sukawati masih belum tersedia. Dewasa ini peta yang tersedia di lapangan bersumber dari Dinas Kebudayaan Daerah Kabupaten Gianyar tapi tidak menggambarkan keadaan pariwisata di Kecamatan Sukawati, seperti peta yang terpasang di depan objek wisata Pasar Seni Sukawati yang hanya menggambarkan keadaan DAS Pakerisan Tampaksiring dengan objek wisata disekitar seperti Pura Tirta Empul, Pura Mangening, Pura Pegulingan, Pura Gunung Kawi, Subak Pulagan, Subak Kulub Atas, dan Subak Kulub Bawah. Distribusi objek wisata dapat diketahui dengan lebih mudah melalui media seperti Peta Wisata, sebab jika tidak digambarkan dalam bentuk peta, persebaran tersebut hanya akan bersifat informasi deskriptif.

Peta Wisata Gianyar Bali \& Surroundings Map merupakan media peta wisata terbaik yang ada di Bali saat ini. Keunggulan dari peta tersebut adalah mudah dibawa karena bisa dilipat dan 
informasi wisata yang ditawarkan beranekaragam, sedangkan kekurangan dari peta ini menurut peneliti adalah dari kuantitas di lapangan, pembaharuan informasi data, dan komponen peta yang masih kurang. Dari segi kuantitas keberadaan Peta Wisata Gianyar Bali \&Surroundings Map hanya tersedia pada objek wisata yang dikelola oleh Dinas Pariwisata Daerah Kabupaten Gianyar yakni Goa Gajah, Tirta Empul, Gunung Kawi Tampaksiring, Gunung Kawi Sebatu, Yeh Pulu, Alam Sidan, dan Bukit Jati dengan kuantitas yang terbatas, selain itu ketersediaan peta online di website Dinas Pariwisata Daerah Kabupaten Gianyar masih belum dicantumkan hingga kini. Pemetaan lokasi desa wisata dapat memberikan kemudahan bagi para wisatawan untuk pengaksesan lokasi dan pemilihan desa wisata yang akan dituju (Fauzy dan Putra, 2015). Informasi yang tersaji pada peta sampai saat ini hanya menggambarkan kondisi pariwisata pada tahun 2015 sehingga data pariwisata yang ada belum diperbaharui, khususnya daerah tujuan wisata yang ada di Kecamatan Sukawati hingga tahun 2018 sudah mengalami perubahan. Disisi lain kekurangan komponen pada peta terletak pada tidak adanya skala peta, kordinat peta, letering dan sumber peta.

Keterbatasan jumlah peta seperti ini tentu dapat menurunkan eksistensi pariwisata yang ada. Wisatawan cenderung melakukan perjalanan wisata tidak lagi sebagai mass tourism, tetapi sebagai kelompok kecil yang memiliki motif untuk mengadakan petualangan dengan mengunjungi daerah tujuan wisata yang relatif belum banyak terganggu oleh perubahan fisik dan teknologi dalam penataannya, termasuk didalamnya masyarakat yang relatif masih tradisional dalam berperilaku (Suriani dan Razak, 2011). Wisatawan yang berkunjung tanpa menggunakan jasa guide biasanya memiliki pengetahuan spasial terbatas dari lingkungan yang didatangi, tentu hal iniakan menyulitkan mereka untuk mengetahui daerah tujuan wisatayang tersebar (Eboy, 2017). Peta Wisata memainkan peran penting dalam dunia kepariwisataan baik untuk media pembelajaran atau memperoleh informasi tentang tempat-tempat wisata di sekitar kita.

Oleh karena itu, agar dapat memberikan layanan yang baik dalam industri pariwisata, peneliti mencoba membangun sebuah produk berupa peta yang dapat menyediakan informasi untuk mendukung perjalanan wisata para wisatawan selama berada di Kecamatan Sukawati dengan menggunakan teknologi komputer yakni software ArcGIS 10.3. Untuk itu dibutuhkan prosedur atau format pemetaan pariwisata yang tepat untuk menghasilkan peta wisata yang akurat, dapat diandalkan, dan diproduksi melalui sebuah penelitian.

\section{Metode}

Penelitian ini dirancang sebagai penelitian deskriptif dengan menggunakan pendekatan keruangan. Rancangan penelitian dibuat sebagai pedoman untuk melakukan sebuah penelitian. Pendeskripsian dalam penelitian ini yaitu: (1) Karakteristik objek wisata di Kecamatan Sukawati, (2) Tingkat kelayakan pengembangan objek wisata di Kecamatan Sukawati, (3) Pemetaan distribusi objek wisata di Kecamatan Sukawati.

Populasi pada penelitian ini adalah semua objek wisata yang tersebar di Kecamatan Sukawati. Sampel dalam penelitian ini ditentukan berdasar tehknik purposive sampling dengan pertimbangan spasial yaitu kawasan wisata Desa Ketewel, Desa Kemenuh, dan Desa Singapadu. Metode pengumpulan data yang digunakan pada penelitian ini yaitu observasi, wawancara, angket, dokumentasi, dan pencatatan dokumen. Metode dan tehknik analisis yang digunakan untuk mengetahui karakteristik adalah deskriptif kualitatif dan untuk tingkat kelayakan pengembangan objek wisata menggunakan Pedoman Analisis Daerah Operasi Objek Wisata dan Daya Tarik Wisata Alam Dirjen PHKA Tahun 2003. Jumlah nilai untuk satu kriteria penilaian ODTW dapat dihitung dengan persamaan sebagai berikut. 


$$
\mathrm{S}=\mathrm{N} \times \mathrm{B}
$$

Dimana: $\mathrm{S}=$ skor/nilai suatu kriteria, $\mathrm{N}=$ jumlah nilai unsur-unsur pada kriteria, $\mathrm{B}=$ bobot nilai. Kriteria daya tarik diberi bobot 6 karena faktor utama dalam berwisata, aksesibilitas diberi bobot 5 karena faktor penting untuk mendukung wisatawan dalam melakukan kegiatan, dan untuk akomodasi serta sarana dan prasarana penunjang diberi bobot 3 karena bersifat sebagai penunjang dalam kegiatan wisata.

Menurut Karsudi ( dalam Barus dkk 2013)menyatakan setelah dilakukan perbandingan, maka akan diperoleh indeks kelayakan dalam persen. Indeks kelayakan suatu kawasan wisata adalah sebagai berikut:

- Tingkat kelayakan > 66,6\% : layak dikembangkan, dengan kriteria suatu kawasan wisata yang memiliki potensi, sarana dan prasarana yang tinggi berdasarkan parameter yang telah ditetapkan serta didukung oleh aksesibilitas yang memadai.

- Tingkat kelayakan 33,3\% - 66,6\% : belum layak dikembangkan, dengan kriteria suatu kawasanwisata yang memiliki potensi, sarana dan prasarana yang sedang berdasarkan parameter yang telah ditetapkan serta didukung oleh aksesibilitas yang cukup memadai.

- Tingkat kelayakan < 33,3\% : tidak layak dikembangkan, dengan kriteria suatu kawasan wisata yang memiliki potensi, sarana dan prasarana yang rendah berdasarkan parameter yang telah ditetapkan serta aksesibilitas yang kurang memadai.

\section{Hasil dan pembahasan}

\subsection{Karakteristik Objek Wisata Di Kecamatan Sukawati}

Karakteristik objek wisata yang ada di Kecamatan Sukawati seperti terlihat pada Tabel 1.

Tabel 1.Wisata Alam di Kecamatan Sukawati

\begin{tabular}{clcc}
\hline \multirow{2}{*}{ No } & \multicolumn{3}{c}{ Wisata Alam di Kecamatan Sukawati } \\
\cline { 2 - 4 } & \multicolumn{1}{c}{ Nama Objek Wisata } & Lokasi/ Desa & Bentuk \\
\hline $\mathbf{1 1}$ & \multicolumn{1}{c}{$\mathbf{( 2 )}$} & Guwang & (4) \\
\hline 1 & Hidden Canyon Beji & Bgarai dan Sungai \\
& Guwang & Batuan & Ngarai dan Sungai \\
2 & Negara Countryside & Kemenuh & \\
& Trecking & Sukawati & Air Terjun \\
3 & Air Terjun Tegenungan & Ketewel & Pantai \\
4 & Pantai Purnama & Ketewel & Pantai \\
5 & Pantai Rangkan & Ketewel & Pantai \\
6 & Pantai Ketewel & & Pantai \\
7 & Pantai Lembeng & &
\end{tabular}

Sumber : Hasil Observasi Peneliti, 2019

Tabel 2.Wisata Budaya di Kecamatan Sukawati

\begin{tabular}{cccc}
\hline \multirow{2}{*}{ No } & \multicolumn{3}{c}{ Wisata Budaya di Kecamatan Sukawati } \\
\cline { 2 - 4 } & \multicolumn{1}{c}{ Nama Objek Wisata } & Lokasi/ Desa & Bentuk \\
\hline (1) & \multicolumn{1}{c}{$\mathbf{( 2 )}$} & Batuan & (4) \\
\hline 1 & $\begin{array}{l}\text { Cagar Budaya Pura Desa } \\
\text { Batuan }\end{array}$ & Bangunan Suci berjarah \\
2 & $\begin{array}{l}\text { Cagar Budaya Pura Puseh } \\
\text { Canggi }\end{array}$ & Batuan Kaler & Bangunan Suci berjarah
\end{tabular}




\begin{tabular}{clcc}
3 & Putra Barong & Celuk & Pementasan Seni Tari \\
4 & Stage Puseh Batubulan & Batubulan & Pementasan Seni Tari \\
\hline 5 & $\begin{array}{l}\text { Jambe Budaya Barong dan } \\
\text { Keris Dance }\end{array}$ & Batubulan & Pementasan Seni Tari \\
Sahadewa Barong dan & Batubulan & Pementasan Seni Tari \\
Keris & & \\
\hline
\end{tabular}

Sumber : Gianyar Bali and Surroundings Map 2015 dan Hasil Observasi Peneliti

Tabel 3.Wisata Buatan di Kecamatan Sukawati

\begin{tabular}{cccc}
\hline \multirow{2}{*}{ No } & \multicolumn{3}{c}{ Wisata Buatan di Kecamatan Sukawati } \\
\cline { 2 - 4 } & Nama Objek Wisata & Lokasi/ Desa & Bentuk \\
\hline $\mathbf{( 1 )}$ & $\mathbf{( 2 )}$ & $\mathbf{( 3 )}$ & (4) \\
\hline 1 & Bali Zoo Park & Singapadu & Kebun Binatang \\
2 & Bali Bird Park & Batubulan & Kebun Binatang \\
3 & Kemenuh Butterfly Park & Kemenuh & Kebun Binatang \\
4 & Museum Seni Batuan & Batuan & Museum Lukisan \\
\hline \multicolumn{4}{l}{ Sumber : Gianyar Bali and Surroundings Map 2015 dan Hasil Observasi Peneliti }
\end{tabular}

Tabel 4.Wisata Minat Khusus di Kecamatan Sukawati

\begin{tabular}{cccc}
\hline \multirow{2}{*}{ No } & \multicolumn{2}{c}{ Wisata Minat Khusus di Kecamatan Sukawati } \\
\cline { 2 - 4 } & Nama Objek Wisata & Lokasi/ Desa & Bentuk \\
\hline (1) & $\mathbf{( 2 )}$ & (3) & (4) \\
\hline 1 & Pasar Seni Sukawati 1 & Sukawati & Pasar \\
2 & Pasar Seni Sukawati 2 & Guwang & Pasar \\
3 & Pasar Seni Sukawati 3 & Celuk & Pasar \\
\hline
\end{tabular}

Sumber : Gianyar Bali and Surroundings Map 2015 dan Hasil Observasi Peneliti

\subsection{Tingkat Kelayakan Pengembangan Objek Wisata Di Kecamatan Sukawati}

Tabel 5.

Hasil Penilaian Tingkat Kelayakan Pengembangan Objek Wisata di Kawasan Desa Ketewel

\begin{tabular}{cccccccc}
\hline No & Kriteria/Unsur & Bobot & Nilai* $^{*}$ & Skor** & $\begin{array}{c}\text { Skor Max } \\
* * *\end{array}$ & $\begin{array}{c}\text { Indeks (\%) } \\
* * * *\end{array}$ & Keterangan \\
\hline $\mathbf{( 1 )}$ & $\mathbf{( 2 )}$ & $\mathbf{( 3 )}$ & $\mathbf{( 4 )}$ & $\mathbf{( 5 )}$ & $\mathbf{( 6 )}$ & $\mathbf{( 7 )}$ & $\mathbf{( 8 )}$ \\
\hline 1 & Daya tarik & 6 & 82 & 490 & 900 & 54 & Belum layak \\
2 & Aksesibilitas & 5 & 123 & 617 & 750 & 82 & Layak \\
3 & Sarana dan & 3 & 50 & 150 & 300 & 50 & Belum layak \\
\hline & Prasarana & \multicolumn{7}{c}{ Tingkat kelayakan } & & 62 & Belum layak \\
\hline
\end{tabular}

*Hasil penilaian terhadap objek dan daya tarik wisata

**Perkalian antara bobot dengan nilai

***Skor tertinggi untuk setiap kriteria

****Indeks kelayakan: perbandingan skor dengan skor tertinggi dalam $\%$

Tabel 6.

Hasil Penilaian Tingkat Kelayakan Pengembangan Objek Wisata di Kawasan Desa Kemenuh

\begin{tabular}{cccccccc}
\hline No & Kriteria/Unsur & Bobot & Nilai* & Skor** & $\begin{array}{c}\text { Skor Max } \\
* * *\end{array}$ & $\begin{array}{c}\text { Indeks (\%) } \\
* * * *\end{array}$ & Keterangan \\
\hline $\mathbf{( 1 )}$ & $\mathbf{( 2 )}$ & $\mathbf{( 3 )}$ & $\mathbf{( 4 )}$ & $\mathbf{( 5 )}$ & $\mathbf{( 6 )}$ & $\mathbf{( 7 )}$ & $\mathbf{( 8 )}$ \\
\hline 1 & Daya tarik & 6 & 98 & 531 & 900 & 59 & Belum layak \\
2 & Aksesibilitas & 5 & 118 & 533 & 750 & 71 & Layak
\end{tabular}




\begin{tabular}{cccccccc}
3 & $\begin{array}{c}\text { Sarana dan } \\
\text { Prasarana }\end{array}$ & 3 & 70 & 210 & 300 & 70 & Layak \\
\hline \multicolumn{4}{c}{ Tingkat kelayakan } & & & 67 & Layak \\
\hline
\end{tabular}

*Hasil penilaian terhadap objek dan daya tarik wisata

**Perkalian antara bobot dengan nilai

***Skor tertinggi untuk setiap kriteria

****Indeks kelayakan: perbandingan skor dengan skor tertinggi dalam $\%$

Tabel 7.

Hasil Penilaian Tingkat Kelayakan Pengembangan Objek Wisata di Kawasan Desa Singapadu

\begin{tabular}{cccccccc}
\hline No & Kriteria/Unsur & Bobot & Nilai* & Skor** & $\begin{array}{c}\text { Skor Max } \\
* * *\end{array}$ & $\begin{array}{c}\text { Indeks (\%) } \\
* * * *\end{array}$ & Keterangan \\
\hline $\mathbf{( 1 )}$ & $\mathbf{( 2 )}$ & $\mathbf{( 3 )}$ & $\mathbf{( 4 )}$ & $\mathbf{( 5 )}$ & $\mathbf{( 6 )}$ & $\mathbf{( 7 )}$ & $\mathbf{( 8 )}$ \\
\hline 1 & Daya tarik & 6 & 101,1 & 607 & 900 & 67,4 & Layak \\
2 & Aksesibilitas & 5 & 125 & 623,3 & 750 & 83,1 & Layak \\
3 & Sarana dan & 3 & 92 & 276 & 300 & 92 & Layak \\
\hline & Prasarana & \multicolumn{7}{c}{ Tingkat kelayakan } & & 81 & Layak
\end{tabular}

*Hasil penilaian terhadap objek dan daya tarik wisata

**Perkalian antara bobot dengan nilai

***Skor tertinggi untuk setiap kriteria

****Indeks kelayakan: perbandingan skor dengan skor tertinggi dalam $\%$

Tabel 8.

Hasil Penilaian Tingkat Kelayakan Pengembangan Objek Wisata di Kecamatan Sukawati

\begin{tabular}{cccccc}
\hline \multicolumn{5}{c}{ Tingkat Kelayakan Pengembangan Objek Wisata Di Kecamatan Sukawati } \\
\cline { 3 - 5 } No & \multirow{3}{*}{ Kriteria } & Ketewel (\%) & Kemenuh (\%) & Singapadu & \multirow{2}{*}{ Total } \\
\cline { 3 - 5 } & & $(3)$ & $(4)$ & $(5)$ & $(6)$ \\
\hline$(1)$ & 54 & 59 & 67 & 60 \\
\hline 1 & Daya tarik & 82 & 71 & 83 & 79 \\
2 & Aksesibilitas & 50 & 70 & 92 & 71 \\
3 & Sarana dan prasarana & 62 & 67 & 81 & 70 \\
\hline Tingkat kelayakan & & & & \multirow{2}{*}{ pengembangan }
\end{tabular}

\subsection{Pemetaan Distribusi Objek Wisata Di Kecamatan Sukawati}

Pemanfaatn ArcGIS 10.3 membantu dalam mengolah dan memanipulasi data yang telah diperoleh dari hasil observasi lapangan, dokumentasi, data dari instansi terkait, dan lain sebagainya (Yussuf dkk, 2015).

Berdasarkan data karakteristik objek wisata dan penilaian dari tingkat kelayakan pengembangan objek wisata di Kecamatan Sukawati, peneliti dapat menghasilkan 2 buah peta khusus. Adapun peta-peta yang dimaksud seperti terlihat pada Gambar 1. 


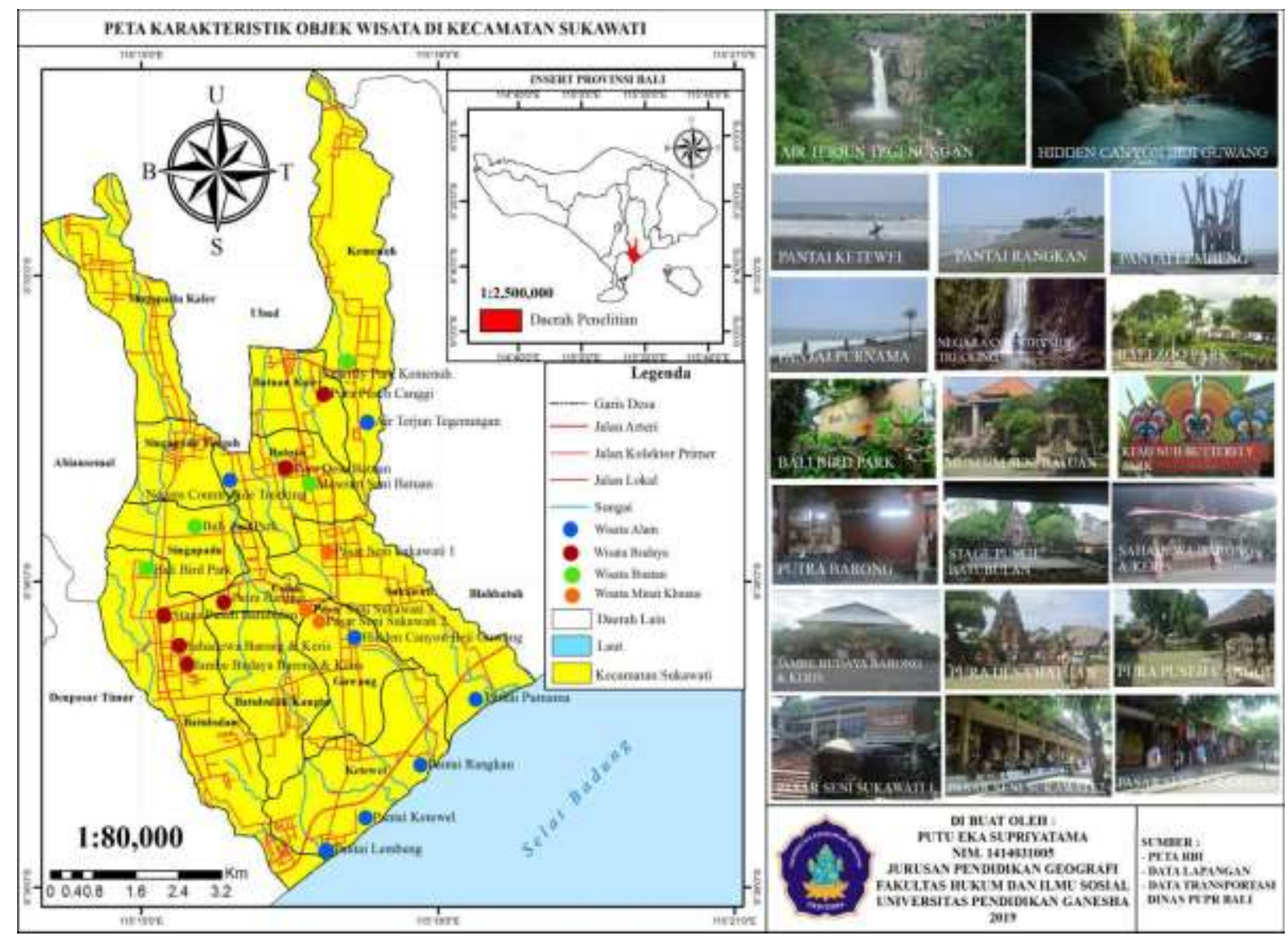

Gambar 1.

Peta Karakteristik Objek Wisata Di Kecamatan Sukawati

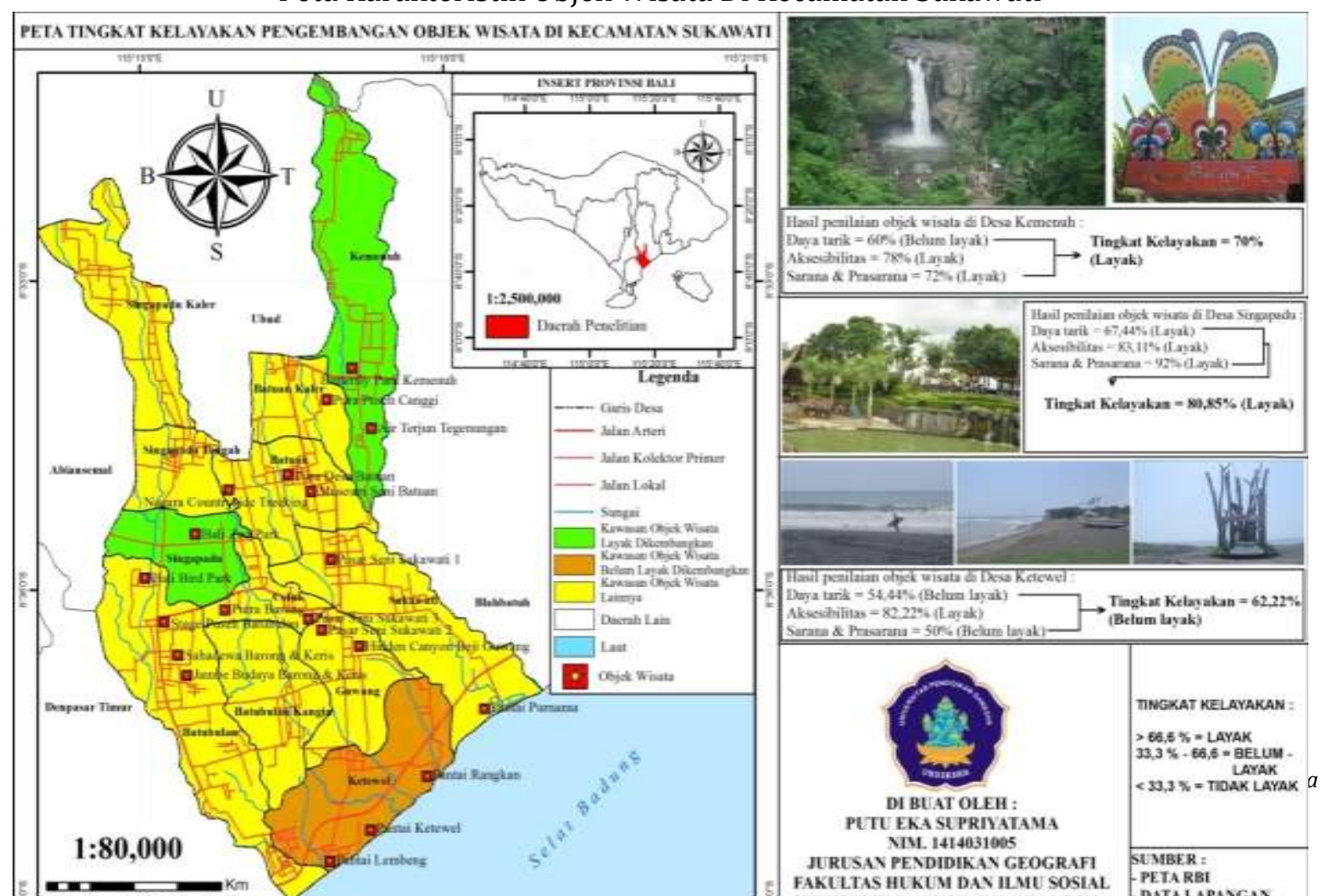


Gambar 2.

Peta Tingkat Kelayakan Pengembangan Objek Wisata Di Kecamatan Sukawati

\subsection{Karakteristik Objek Wisata Di Kecamatan Sukawati}

Objek wisata yang tersebar di Kecamatan Sukawati berjumlah 20 buah. Keseluruhan objek tersebut berupa 7 buah wisata alam, 6 buah wisata budaya, 4 buah wisata buatan, dan 3 buah wisata minat khusus. Meskipun Kecamatan Sukawati terkenal dengan daerah seni budaya, hasil yang peneliti peroleh di lapangan memperlihatkan bahwa objek wisata alam lebih dominan dari objek wisata budaya. Fenomena ini disebabkan karena seni budaya yang melekat pada wujud fisik dan sosial masyarakat di Kecamatan Sukawati dipengaruhi oleh konsep Desa Kala Patra yakni penyesuaian diri sesuai dengan tempat, waktu, dan keadaan kita berada (Darmada, 2016). Konsep ini memengaruhi seni budaya di setiap desa yang ada.

Wujud fisik dapat berupa bangunan yang mampu menampung hasil kesenian yang memiliki nilai estetika seperti gallery dan museum dengan struktur bangunan dan manajemen yang baik. Untuk wujud sosial dapat berupa upacara keagamaan dan seni tari atau kerawitan yang umumnya menyesuaikan dengan hari raya umat Hindu dan penanggalan Kalender Saka dengan artian tidak dapat ditemukan hampir setiap hari. Walaupun demikian keberadaanya masih mampu menjadi daya tarik tambahan dari objek wisata di Kecamatan Sukawati. Contoh daya tarik tambahan yang dimaksud baik yang berupa wujud fisik dan sosial masyarakat adalah seperti seni patung yang ada di Desa Batubulan, seni ukir di Desa Singapadu dan tradisi Mepeed di Desa Sukawati.

Pembeda penelitian ini dengan lainnya dapat dilihat dari hasil penelitian (Ariasa, 2017). Penelitian Ariasa (2017) pada aspek karakteristik wisata yang ada di Kecamatan Nusa Penida memiliki 3 jenis wisata atau karakteristik yang berbeda yaitu (1) wisata bahari, (2) wisata alam, (3) wisata budaya. Di Kecamatan Sukawati karakteristik budaya ini dapat ditemukan lebih beragam karena tidak hanya budaya yang ada pada tempat suci melainkan budaya dalam bentuk berupa tarian barong dan keris.

\subsection{Tingkat Kelayakan Pengembangan Objek Wisata Di Kecamatan Sukawati}

1. Belum Layak Dikembangkan

Kawasan objek wisata di Desa Ketewel memperoleh nilai 62\%, kawasan ini memiliki 3 objek wisata yaitu objek wisata Pantai Rangkan, Ketewel, dan Lembeng. Unsur yang menyebabkan kawasan ini belum layak dikembangkan adalah kurangnya daya tarik utama, kegiatan yang bisa dilakukan terbatas seperti berenang jika kondisi cuaca mendukung dan melihat kebudayaan seperti melasti yang dilaksanakan bulan-bulan tertentu, serta kondisi tempat yang sewaktu-waktu bisa kotor oleh sampah yang jarang terurus. Disisi lain penduduk lokal disana belum mampu mengelola dan mengembangkan potensi ombak besar di pantai ini menjadi wisata surfing. Unsur aksesibilitas, jalan menuju lokasi objek ini tergolong baik, jarak dari pusat kota dan bandara cukup terjangkau dengan waktu tempuh 
tidak terlalu lama. unsur yang terakhir adalah sarana dan prasarana penunjang yang masih kurang. Di lokasi ini hanya terdapat warung kecil, jaringan listrik dan area parkir.

2. Layak Dikembangkan

Kawasan objek wisata di Desa Kemenuh memperoleh nilai 67\% dengan 2 objek wisata yaitu Air Terjun Tegenungan dan Butterfly Park Kemenuh. Unsur yang mempengaruhi kawasan ini layak dikembangkan adalah daya tarik utama seperti satwa kupu-kupu, air terjun, daya tarik tambahan seperti sungai, dan kolam pemandian. Keberadaan daya tarik tambahan adalah sebagai pendukung dari daya tarik utama (Wijana dkk, 2018). Aktifitas yang dapat dilakukan beragam seperti berenang, berswa foto, dan tracking. Unsur aksesibilitas, jalan menuju lokasi objek ini tergolong baik, terjangkau dari pusat kota dan bandara dengan waktu tempuh tidak terlalu lama. Terakhir adalah sarana prasarana penunjang lengkap seperti rumah makan, area parkir, toko cenderamata, jaringan air minum, jaringan telepon/wifi, dan jaringan listrik.

Kawasan objek wisata di Desa Singapadu memperoleh nilai 81\%, kawasan ini memiliki 1 objek wisata yaitu Bali Zoo Park. Unsur yang mempengaruhi kawasan ini layak dikembangkan adalah daya tarik utama seperti aneka satwa. Daya tarik tambahannya adalah wahana air, kolam gajah, dan memberi makan rusa. Selanjutnya yang mempengaruhi adalah aksesibilitas, jalan menuju lokasi objek ini baik, jarak dari pusat kota dan bandara terjangkau dengan waktu tempuh tidak lama. Terakhir adalah sarana prasarana penunjang yang sangat lengkap seperti rumah makan, vila, ATM, parkir, pos kesehatan, keamanan, jaringan listrik, telepon, dan air

Berdasarkan hasil penelitian pemetaan yang dapat dilakukan oleh peneliti adalah sebagai berikut:

1. Peta Karakteristik Objek Wisata Di Kecamatan Sukawati

Adapun sebaran dari karakteristik atau jenis wisata adalah sebagai berikut:

1) Wisata Alam

Objek wisata yang berupa wisata alam di Kecamatan Sukawati tersebar di Desa Batuan,

Desa Sukawati, Desa Ketewel, Desa Guwang, dan Desa Kemenuh dengan objek paling dominan adalah pantai.

2) Wisata Budaya

Objek wisata yang berupa wisata budaya di Kecamatan Sukawati tersebar di Desa Batuan

Kaler, Desa Batuan, Desa Celuk, dan Desa Batubulan dengan objek paling dominan adalah Barong and Keris Dance.

3) Wisata Buatan

Objek wisata yang berupa wisata buatan di Kecamatan Sukawati tersebar di Desa Batuan,

Desa Singapadu, Desa Kemenuh, dan Desa Batubulan dengan objek paling dominan adalah kebun binatang.

4) Wisata Minat Khusus

Objek wisata yang berupa wisata minat khusus di Kecamatan Sukawati tersebar di Desa

Sukawati, Desa Celuk, dan Desa Guwang dengan keseluruhan objek berupa pasar seni.

Hasil akhir diperoleh Desa Kemenuh indeks 67\% = layak dikembangkan, Desa Singapadu indeks $81 \%$ = layak dikembangkan, Desa Ketewel indeks 62\% = belum layak dikembangkan. Total penjumlahan diperoleh $210 / 3=70 \%$ dengan demikian Tingkat Kelayakan Pengembangan Objek Wisata di Kecamatan Sukawati layak untuk dikembangkan.

\section{Simpulan dan saran}


Kecamatan Sukawati memiliki 20 objek wisata yang terbagi menjadi 7 wisata alam, 6 wisata budaya, 4 wisata buatan, dan 3 wisata minat khusus.Kawasan wisata di Kecamatan Sukawati layak dikembangkan karena memperoleh total indeks nilai $70 \%$.Hasil penelitian ini memperoleh dua buah peta yaitu Peta Karakteristik dan Peta Tingkat Kelayakan Pengembangan. Peta Karakteristik memberikan informasi atau gambaran mengenai distribusi atau sebaran objek wisata dengan masing-masing jenisnya di Kecamatan Sukawati, sedangkan Peta Tingkat Kelayakan pengembangan lebih menekankan pada kawasan atau objek wisata mana yang layak atau belum layak untuk dikembangkan.

Berdasarkan hasil pembahasan, maka disarankan bagi peneliti lain selanjutnya dapat melakukan penelitian mengenai karakteristik khusus mengenai salah satu objek wisata di Kecamatan Sukawati dengan variabel yang berbeda.Penelitian ini dapat dijadikan sebagai bahan pertimbangan untuk pemerintah dalam perencanaan pembangunan pada sektor pariwisata di Kecamatan Sukawati.Penelitian ini dapat dijadikan sebagai media informasi mengenai sebaran objek wisata yang ada di Kecamatan Sukawati.

\section{Daftar Rujukan}

Ariasa, I. K. A. (2017). Pemetaan Potensi Wisata Dengan Sistem Informasi Geografis Di Kecamatan Nusa Penida Kabupaten Klungkung. Universitas Pendidikan Ganesha.

Barus, Sekar Indah Putri, Patana, Pindi, A. Y. (2013). Analisis Potensi Objek Wisata dan Kesiapan Masyarakat dalam Pengembangan Desa Wisata Berbasis Masyarakat di Kawasan Danau Linting Kabupaten Deli Serdang. Jurnal Bidang Kehutanan, 2(2), 144-145.

Darmada, I. M. (2016). STUDI ETNOGRAFI PADA BUDAYA LOKAL SEBAGAIPENGEMBANGAN KREATIVITAS DALAM KONTEKS INDUSTRI KREATIF. SEMINAR NASIONAL RISET INOVATIF (SENARI) KE-4TAHUN 2016. Retrieved from http://eproceeding.undiksha.ac.id/index.php/senari/article/view/778/550

Eboy, O. V. (2017). Tourism Mapping An Overview Of Cartpgraphy and The Use Of GIS. Journal for Suastinable Tourism Development, 6(1).

Fauzy, Akhmad dan Putra, A. S. (2015). PEMETAAN LOKASI POTENSI DESA WISATA DI KABUPATEN SLEMAN TAHUN 2015. Jurnal Inovasi Dan Kewirausahaan, 4(2), 124-129. Retrieved from https://www.researchgate.net/profile/Akhmad_Fauzy/publication/307938757_PEMETAA N_LOKASI_POTENSI_DESA_WISATA_DI_KABUPATEN_SLEMAN_TAHUN_2015/links/58a2be f345851598babcd82a/PEMETAAN-LOKASI-POTENSI-DESA-WISATA-DI-KABUPATENSLEMAN-TAHUN-2015.pdf

S, Richard R F, Satoto, Kodrat Imam, Martono, K. T. (2014). IMPLEMENTASI SISTEM INFORMASI GEOGRAFIS DAERAH PARIWISATAKOTA SEMARANG BERBASIS ANDROID DENGAN GLOBAL POSITIONINGSYSTEM(GPS). Jurnal Teknologi Dan Sistem Komputer, 2(1). Retrieved from https://jtsiskom.undip.ac.id/index.php/jtsiskom/article/view/4764/4586

Simamora, Rotua Kristin dan Sinaga, R. S. (2016). Peran Pemerintah Daerah dalam Pengembangan Pariwisata Alam dan Budaya di Kabupaten Tapanuli Utara. Jurnal Ilmu Pemerintahan Dan Sosial Politik, 4(1), 79-96. Retrieved from http://ojs.uma.ac.id/index.php/jppuma/article/view/895/895

Subhani, A. (2010). POTENSI OBYEK WISATA PANTAI DI KABUPATEN LOMBOK TIMUR TAHUN 2010 (Universitas Sebelas Maret). Retrieved from https://eprints.uns.ac.id/8236/

Suriani, Nur Emma dan Razak, M. N. (2011). Pemetaan Potensi Ekowisata di Taman Nasional Baluran. 24(3), 251-260. Retrieved from http://journal.unair.ac.id/filerPDF/08 emma nurdin pemetaan potensi_editan tyas.pdf

Wijana, I Nyoman, Wesnawa, I. G. A. (2018). The Mapping Of Rare Plant Species Distribution Monkey Forest, Ubud, Gianyar, Bali. Jurnal Media Komunikasi Geografi, 19(1), 28. 